\title{
Purely Consequentialist Legal Activism in the Brazilian Criminal Constitutional Jurisdiction based on Case Studies in the Jurisprudence of the Supreme Federal Court
}

\section{Minervino Quintiere V* \\ Doctor Student in Law, Braziliense Institute of Public Law, Brazil}

*Corresponding author: Víctor Minervino Quintiere, Doctor Student in Law, Braziliense Institute of Public Law (IDP), Brazil, Email: victor_minervino@hotmail.com

\section{Review Article}

Volume 4 Issue 3

Received Date: July 21, 2021

Published Date: August 30, 2021

DOI: $10.23880 /$ abca-16000195

\section{Abstract}

The present study intended, based on the use of the methodology related to legal consequentialism, the field of consequentialist argumentation and possible risks of its use by judges, in particular, those who perform constitutional jurisdiction and efficient speeches and the concept of purely consequentialist activism, assess whether, and to what extent, it would be possible to divide the concept of purely consequentialist activism into degrees according to the legal nature of the decision handed down within the scope of the Supreme Federal Court, more specifically, with regard to the (non) provisionality of the decision. Throughout the work it was possible to divide purely consequentialist activism into two species. The first of these, called first degree consequentialist activism, characterized by monocratic decisions or judgments that respect the limits of merit and, consequently, the principle of collegiality, and; second-degree consequentialist activism, characterized by monocratic decisions that, not meeting the limits of precautionary decisions, end up disrespecting the principle of collegiality.

Keywords: Constitutional Right; Criminal Law; Legal Dogmatics; Legal Consequentialism; Federal Court of Justice; Jurisprudence

\section{Introduction}

The present study, based on the analysis of legal Consequentialism and the concept of purely consequentialist judicial activism brought by Georges A, et al. [1], aims to analyze whether, within this concept, it would be possible to divide it into degrees based on the Legal nature of the decision issued, more specifically with regard to the (non) provisional nature of the decision and its effects on the constitutional jurisdictional provision.

For this, in the first chapter, a retrospective analysis of the so-called analysis of consequences in law will be carried out, the objective of which is to establish the parameters for the study of said theory, either at the international or national level. In this sense, the concept of consequentialism will be highlighted, its relationship with moral philosophy, with utilitarian tradition, with pragmatism and, finally, with law itself. Then, in this chapter, the field of consequent argumentation and the possible risks of its use by judges, in particular those who exercise constitutional jurisdiction will be developed, based on Neil M, et al. [2].

The examination of the consequences pursued in the activity of the judge, as well as the examination of the efficient legal argumentation (and possible risks) will allow to extract the concept of purely consequentialist judicial activism so that, then, the jurisprudential analysis of said institute is 
possible. Within the scope of the Brazilian Constitutional Court (STF).

Next, in the second topic, they will be analyzed, through research of a qualitative nature and that adopted, as a methodology, documentary research in jurisprudence and bibliography, precedents judged by the Supreme Federal Court, in criminal matters, between the years 2018 to 2020, so that it is possible to measure whether these courts serve as an example of purely consequential activist positions.

In the third chapter, starting from the theoretical bases of legal consequentialism, purely consequentialist activism and the correlations (not) possible to be made with the precedents chosen for study, it will be possible to answer the research problem that was proposed to answer at the beginning, whatever: to what extent would it be possible to divide the concept of purely consequentialist activism into degrees according to the legal nature of the sentence handed down in the sphere of the Supreme Court, more specifically, in relation to the (non) provision of the decision?

\section{That they understand the Theoretical bases of Consequentialist Judicial Activism}

Before answering the aforementioned question, it is necessary to establish the bases on which such an examination will be possible, that is, on the functions of the analysis of the consequences in Law. In this sense, the initial analysis of consequentialist judicial activism, in the light of Georges A, et al. [1], will include the comparison of the consequences carried out in the decision-making activity of judges based on Ronald D, et al. $[3,4]$ and his conception of law as integrity. After this study and possible correlations with the work of Lionel Adolphus $\mathrm{H}$, et al. [5], it will be possible to properly analyze consequentialism and its relationship with the Law.

The analysis proposal based on Ronald D, et al. $[3,4]$ acquires meaning when starting from a first collation consisting of understanding the analysis of the consequences as a key factor to maintain a chain of meanings in jurisprudence and in the legitimacy of the decisions of the judge.

Before analyzing the exit for hard cases proposed by Ronald D, et al. [3] it is important to bring the theoretical counterpoint that led to its conclusion, whatever it may be: his interlocution with Lionel Adolphus H, et al. [5], in the field of legal theory.

Lionel Adolphus $\mathrm{H}$, et al. [5], in synthesis, while conferring the nomenclature of "easy cases" to all the questions considered incontrovertible of fixing the meaning of the norm, considers them as "difficult cases" or, even, "zone of penumbra "when the norm is presented in such a way that the law does not provide a clear solution for the case analyzed.

That is, given the lack of clarity in the only possible answer, as occurs in the so-called "easy cases", for Lionel Adolphus $\mathrm{H}$, et al. [5], the judge should choose one, among the interpretive alternatives available, through discretion. After the departure proposed by Lionel Adolphus $\mathrm{H}$, et al. [5], it is possible to identify the point of divergence presented by Ronald D, et al. [3], for which the Law must be seen as integrity. For the second author, discretion alone would not be a suitable element to respond to difficult cases. For Ronald D, et al. [3], hard cases must be resolved through the investigation made by the judge, on the rights of each party in the case at trial. That is, even if the specific case does not allow a clear answer, even in that hypothesis, the judge who deviates from discretion must resolve the problem on the basis of principled arguments.

Arguments of principle refer to the standards that justify a political decision, showing that it respects or protects the rights of an individual or group. The verification of Law as integrity for Ronald D, et al. [3], therefore, is nothing more than guaranteeing predictability in decisions, as well as conferring legitimacy to the judicial decision by maintaining the chain of determined meanings. by previous decisions, that is, there is prioritization of the principles of the community.

On the subject, Georges A, et al. [1] highlights that "the analysis of the consequences by the judge" serves "as a way to maintain the coherence and integrity of the jurisprudence". Following the analysis of the consequences, a second point of examination refers to the so-called normative consequence. In short, it is the examination of the real effects, at the normative level, that produces a decision in the application of a device Georges A, et al. [1].

Regarding the normative consequences, it is important to specify that a judicial decision, having repercussions on the normative level, could be considered positive or negative ${ }^{\mathbf{1}}$. The focus of this work refers to the possible negative consequences, consectarian of a consequentialist judicial action, that is, when the judge ends up effectively denying the validity of the interpreted device, contrary to the law. After

\footnotetext{
1 Regarding the subject, more specifically on an example of positive consequence, Abboud (2019, p. 3), highlights in verbis: "We can exemplify a positive normative consequence with a constitutional mutation that updates the meaning of a certain normative text and reflects, therefore, the historicity of the interpreter in the face of a new historical moment, extracting a different norm from the normative text from that which until then was carried out by the law enforcement body". Regarding the negative consequences, Abboud in the same text states "By interpreting the device in a certain way, the judge ends up effectively denying the interpreted device validity."
} 
analyzing the functions of the analysis of consequences in law from Lionel Adolphus $\mathrm{H}$, et al. [5] and, mainly, in the light of Ronald D, et al. [3], the next step consists in examining the concept of consequentialism, its relationship with moral philosophy, as the utilitarian tradition, with pragmatism and, finally, with the right itself.

The concept of consequentialism consists of the "peculiar aspect of theological ethics, that is, of the morals that evaluate and prescribe actions with a view to their results, considering behaviors that produce good consequences morally good" Nicola A, et al. [6].

In the field of moral philosophy, the consequences of the action are decisive so that its judgment regarding its correctness is possible, that is, the moral quality of the action and not, the judgment regarding the decision-making in yes Julia D, et al. [7]. Analyzing the concept of consequentialism and its relationship with moral philosophy, it is possible to define it, based on Tim M, et al. [8], that the moral project of consequentialism would be to make the world a better place. In other words, actions that generate the desired effects for the world would make it possible for that same world to become better. The correct thing in this sense of consequence is to carry out acts that produce the best consequences Tim M, et al. [8].

At the core of moral philosophy, among the possibilities of analysis of consequentialism, it is possible to conclude that the main one consists of the utilitarian tradition. From this perspective, according to this tradition, consequentialism can be understood as decision-making aiming at the best consequences, understood as those that maximize the best effects, such as joy or pleasure Christopoulos [9]. Regarding the classical utilitarian tradition, while John Stuart M, et al. [10] defended a graduated hedonism, that is, that certain pleasures such as the intellectual were considered more important than others, Jeremy Bentham defended a more egalitarian hedonism according to Julia D, et al. [7].

At this point, the differences between utilitarianism and consequentialism should be highlighted. In short, while consequentialism is concerned with analyzing consequences without, however, substantially defining what they should be, utilitarianism conceives as desired results those that would be previously known, that is, "An action is morally correct if its result reaches the right greatest possible satisfaction for the largest number of people ".

In pragmatism, a branch of philosophy that consists in the observation of phenomena that have practical incidence Richard R, et al. [11], the interpretation of the normative text for the application of the concrete case has as its final objective the examination of the "practical consequences respective "that is, foreseeable practical results must be taken into account William J, et al. [12]. On the subject, Richard P, et al. [13] affirms that legal pragmatism, while not dealing with concepts and generalizations, by themselves, focuses on examining the facts and consequences. However, this conclusion does not allow confusion between the concepts of pragmatism and consequentialism.

For Richard P, et al. [13], consequentialism is concerned with the best consequences (best Consequences) and pragmatism is based on the judgment of reasonableness, that is, pragmatism is based on the most reasonable decision (reasonableness) for a case concrete.

Analyzing the legal concept of consequence, the Black's Law Dictionary conceptualizes consequentialism as being, in free translation, "an ethical theory that judges the correctness or incorrectness of an action according to its consequences" Bryan AG, et al. [14]. After examining the concept of consequentialism, its relationship with moral philosophy, with the utilitarian tradition, with pragmatism and finally, with the law itself, the next step consists of examining the doctrine of Neil M, et al. [2] which in his work he brings the utilitarian theories closer to the pragmatic ones.

Neil M, et al. [2], although he is not in favor of any of the Dworkin and Hart proposals, highlights that the justification of judicial decisions, due to the consequences, involves two extreme positions: the first in those individuals who believe in the consequences and benefits, although remote, as the only plausible justification for its use; and at the opposite pole, consisting of the second possibility, those who not only do not use as, and also disqualify the use of consequences as suitable elements to justify, in isolation, a judicial decision. In this second vision, it matters little, according to Georges A, et al. [1], "how imminent are" said consequences for the specific case.

In his work, Neil M, et al. [2] draws attention to an important point for this study that, well defined by Georges A, et al. [1], consists in the statement that "The supporters of extreme consequentialism have, in general, of course the existence of some single and ultimate criterion that can serve as a rule to calculate the cost-benefit ratio of the consequences arising from the decision taken ".

From this construction it will be possible to verify whether the action of the Federal Supreme Court, from the perspective of consequentialist judicial activism:

- Exists or not.

- It serves as a rhetorical subterfuge to replace current law with subjectivity or, in fact, it would be allowed within the legal system brought about by the Federal Constitution of 1988. 
- When judging, he refers to the so-called "single rule".

- In the selected precedents, all from the criminal area, there is a burden in empirical data that serve as an accessory to the debated consequences.

\section{The Jurisprudence of the Federal Supreme Court in Criminal Matters between Legal Consequentialism, Scientific Speeches and Purely Consequentialist Judicial Activism}

This topic analyzes the following precedents, in criminal investigation, judged by the Supreme Court, between the years 2018 and 2020, on the basis of the investigation of a qualitative nature and that adopted, as a methodology, the documentary investigation in jurisprudence and bibliography:

- $\quad$ Adin n. 5.526 / DF (2018a) [15] (precautionary measures for parliamentarians).

- Criminal Action n. 937 (2018b) [16] (forum by function prerogative).

- Criminal Investigation n. 4,435 / DF (2019a) [17] (forum by function prerogative).

- Suspension of Liminar n. 1178 / PR (2018c) [18] (interview with former president Luis Inácio Lula da Silva).

- Precautionary measure in ADI n. 6,298 (2020) [19] (Judge of Guarantees).

The choice of the above was based on the following criteria:

- Judgments issued by the Supreme Court.

- $\quad$ Published between the years 2018 to 2020.

- Were initially examined by Georges A, et al. [1] in the text "Legal Consequentialism: the place of the analysis of consequences in law and the dangers of consequentialist judicial activism".

In the Adin n. 5526/DF (2018) [15] in summary, the possibility of application, by the Judiciary, of the precautionary measures provided for in the Code of Criminal Procedure to parliamentarians was discussed. In the present case, the answer was affirmative and it was declared possible to refer the files to the Chamber for examination when the measure makes it impossible, directly or indirectly, to exercise its mandate.

2 Unique rule, for Abboud (2019, p. 4), would consist, in verbis: Although Maccormick rejects both poles of the discussion and recognizes only some consequences as apt to justify judicial decisions, he makes an observation that is absolutely pertinent both to the limits of the present I work as the first pole of the discussion: the supporters of an extreme consequentialism have, in general, as an assumption the existence of some unique and last criterion that can serve as a rule to calculate the cost-benefit relation of the consequences coming from the decision taken. That is the gap to address legal consequentialism in the performance of the Brazilian Judiciary.
In so deciding, the literality of art. $53, \S 2^{3}$, of the Brazilian Federal Constitution of 1988 [20] was not observed, as well as the function of the National Congress, in that case, was subverted to the mere ratifying instance of measures imposed by the Brazilian Constitutional Court. Another issue that deserves to be highlighted within the jurisprudence of the Federal Supreme Court refers to the forum by prerogative of function. Before analyzing what was decided in the Question of Order in Criminal Action. 937 (2018b) [16], important to draw, given the importance of the subject, the legislative panorama and the historical jurisprudence on the subject.

The rules on forum by function prerogative are provided, as a rule, in art. 102, I, "b" and "c"; art. 105, I, "a", all from the CF (1988). Exceptionally, art. 125 , caput and $\S 1 \stackrel{a}{\text { a }}$, of the CF (1988) [20] authorizes the State Constitutions to foresee the hypothesis by prerogative of function in the Courts of Justice, that is, situations in which certain authorities will be originally judged by the Court of Justice. From the collegiate decision of the Supreme Court in the judgment of the Question of Order in the Criminal Process n. 937 (2018b) [16], the understanding was established that the forum by prerogative of function applies only to crimes committed during the exercise of the position and related to it.

Analyzing the votes published in said trial session and relative to the preceding one, there was, on the part of the Supreme Court, not only an attempt to rationalize the "fight against impunity" as a correlation of that value with the premises that:

- The instances lower levels would supposedly be subject to less political pressure.

- That there would be a more rapid processing of processes.

Comparing what was done with everyday situations, there was an attempt, on the part of the Federal Supreme Court, to repair a water leak by simply changing the then existing tap, instead of analyzing the origins of the leak Georges A, et al. [1]. Translating into legal language, the alleged "procedural impunity" of parliamentarians is associated with the large flow of processes throughout the country. Not necessarily, it will be linked to the competence to judge them, according to the interpretation elaborated from the text of Georges A, et al. [1].

On the subject, as well observed by Georges A, et al. [1], "the rule of the" fight against corruption "did not combine with the Federal Constitution, which did not give the forum

$353, \S 2$ from the issuance of the diploma, the members of the National Congress may not be detained, except in inexhaustible flagrant crime. In this case, the files will be sent within twenty-four hours to the respective House, so that, by the vote of the majority of its members, it may decide on the prison. 
by function prerogative the design intended by the majority winner of the Supreme". On that occasion, there was a new interpretative result deduced from the constitutional text, against the scientific argument consisting of the fight against corruption.

The use of the fight against corruption as a suitable filter to interpret art. 53, § 1, of the CF (1988) [20] to relativize the scope of parliamentary immunity by prerogative of forum differs from the conclusions indicated by Andyara Klopstock $S$, et al. [21] in the sense that parliamentary immunities.

- Serve as a means for the realization of representative democracy.

- Its modus operandi consists, among others, in establishing limitations to the action of the Judicial Power when describing formalities.

- They say how the Judicial and Executive Powers should act when establishing formalities that must be fulfilled.

- Must be adopted during the parliamentary term, regardless of the correlation between the offense and the role performed by the accused.

Continuing with the analysis of the courts, in the proceedings of the Regimental Tort in Criminal Investigation n. 4,435/DF (2019a) [17], the Supreme Court examined which judicial body would be competent for the trial of electoral crimes related to common crimes. In addition to the vote disputed in the Supreme Court, consisting of six votes in favor of the prevalence of the jurisdiction of the Electoral Court $^{4}$, against five votes against that position, Criminal Investigation n. 4.435/DF (2019a) [17] draws attention to the use, once again, of the fight against corruption as an argument, in case, capable of defining jurisdictional competence.

During the trial of the case, part of the Supreme Court understood that a greater efficiency of the federal justice to judge common crimes related to electoral crimes and therefore in the fight against corruption, would justify non-compliance with what the Federal Constitution of Brazil (1988) [20] and the infra-constitutional disciplinary legislation on the matter.

Georges A, et al. [1], on the subject, draws attention to the following section of the aforementioned court: "Brazil is experiencing an epidemic in terms of crime. It does not make much difference if the money goes to the pocket or to the campaign. The problem It is not where the money goes, but where the money comes from. And the money comes from the culture of ailment and corruption that has spread throughout the country. “

4 The Mins voted in this regard. Marco Aurélio, Alexandre de Moraes, Ricardo Lewandowski, Gilmar Mendes, Celso de Mello and Dias Toffoli.
From the legal point of view, the competence of the electoral justice as competent for the prosecution of common crimes related to the elections was possible to extract, without major necessities of contemporary interpretive mechanisms, from the arts. 109 and 121, of CF/88 (1988) [20], of arts. 22ㅇ, I, d, of the Electoral Code (1965) [22], and of art. 78º, IV, of the Code of Criminal Procedure (1941) [23]. The great problem of consequentialist activism consists in the modification of the referential present in the laws and that should serve as a structuring element of the decision by the efficiency discourse, totally fleeing from the binomial that should guide the constitutional jurisdiction itself, which is: whether a given law is constitutional or unconstitutional.

The choice of speeches aimed at supposed efficiency, containing within them terms that simply make any discussion such as the fight against corruption or other generic terminology impossible, ultimately removes the normative effectiveness of constitutional and infra-constitutional devices, compromising one of the functions essential of the law that consists in the pacification of conflicts on the basis of the existing set of laws. Another recent decision that deserves to be highlighted and synthesized by Georges A, et al. [1], refers to what happened in the cars of the Suspension of Liminar n. 1178/PR (2018c) [18].

According to said author, it is a provision "of a patently consequentialist nature" and its substance is the suspension of "a precautionary measure previously granted by another minister of the Court and prevented former president Luiz Inácio Lula da Silva from granting an interview to the newspaper, in affront to the freedom to maintain forms of contact with the outside world expressly guaranteed by art. 41, XV of the Criminal Execution Law" Georges A, et al. [1].

Following the sequence of the Supreme Court precedents, to close this issue, it is necessary to mention what happened in the Precautionary Measure in ADI n. 6,298 (2020) [7] However, before examining the underlying issue it-self and the possible consequentialist discourse ${ }^{5}$; it is important to highlight the procedural episodes that attract attention. Originally, it should be noted that this ADI is included in a total of four Direct Actions of Unconstitutionality, which are: ADI 6298, 6299, 6300 and 6305. The focus of the work will be ADI 6298 (2020) [7], more specifically, two Monochrome decisions dictated.

ADI No. 6298 (2020b) [24], adjusted by the Association of Brazilian Magistrates (AMB) and by the Association of Federal Judges of Brazil (AJUFE), implicit.

5 It should be noted that this ADI is included in a total of four ADIS, which are: ADI 6298, 6299, 6300 and 6305. The focus of work will be ADI 6298 (STF, Dje, 02/03/2020). 
- Article 3 of Law n. 13.964/(2019b) [25], which added articles $3^{\circ}-\mathrm{A}, 3^{\circ}-\mathrm{B}, 3^{\circ}-\mathrm{C}, 3^{\circ} \mathrm{D}, 3^{\circ} \mathrm{DE}$ and $3^{\circ}-\mathrm{F}$, to the Code of Criminal Procedure and institutes the figure of the judge of guarantees.

- Article 20 of Law n. 13.964/2019 (2019b) [25], which determines the term of the vacatio legis for the respective validity.

The ADI n. 6.299 (2020b) [24], prosecuted by the political parties PODEMOS and CIUDADANÍA, challenges the same provisions mentioned above, in addition to article 157, $\S 5$, of the Code of Criminal Procedure, inserted by Law no. 13,964 / 2019 (2019b [25]). The ADI n. 6,300 (2020c) [26], prosecuted by the National Directorate of the Liberal Social Party (PSL), challenges articles $3-\mathrm{A}$ to $3 \mathrm{-F}$ of the Code of Criminal Procedure, in the same line of the previous actions.

Finally, ADI n. 6,305 (2020d)[27], prosecuted by the National Association of the Members of the Public MinistryCONAMP, challenges articles 3A; 3B, sections IV, VIII, IX, X and XI; 3rd-D, single paragraph; 28, caput; 28-A, sections III and IV, and §§§; 5th, 7th and 8th; and 310, §4, of the Code of Criminal Procedure, all introduced by Law n. 13,964 / 2019 (2019b) [25].

On January 15, 2020, in Addis cases 6,298, 6,299 and 6,300, Minister President Dias Toffoli, in the exercise of his judicial functions, partially granted the precautionary measures as follows:

1. The effectiveness of the arts. $3^{\circ}-\mathrm{D}$, sole paragraph, and $157, \S 5 \%$, of the Code of Criminal Procedure, included by Law No. 13.964/19 (2019b) [25].

2. The effectiveness of arts. $3^{\circ}-\mathrm{B}, 3^{\circ}-\mathrm{C}, 3^{-}-\mathrm{D}$, caput, $3^{\circ} \mathrm{E}$ and $3^{\circ}-\mathrm{F}$ of the CPP, inserted by Law No. 13,964/2019 (2019b) [25], until the effective implementation of the guarantees by the courts, as which must occur within a maximum period of 180 (one hundred and eighty) days, counted from the publication of this decision.

3. An interpretation has been made in accordance with the rules relating to the judge of guarantees (articles $3^{\circ}-\mathrm{B}$ to $3^{\circ}-\mathrm{F}$ of the CPP), to clarify that they do not apply to the following situations:

$>$ Competition procedures originated by the courts, which are governed by Law No. 8,038/1990 [28].

$>$ Jurisdiction procedures of the Jury Tribunal.

$>$ Cases of domestic and family violence.

$>$ Criminal proceedings within the jurisdiction of the Electoral Justice.

In addition to the previous points, the following transition rules have been established, namely:

- For criminal actions that have already been initiated at the time of the effective application of the guarantees by the courts (or when the the maximum period of 180 days) the effectiveness of the law will not imply any modification of the competent judgment, that is, the fact that the judge of the case has acted in the investigation phase will not imply its automatic impediment.

- For investigations that are underway at the time of the effective application of the guarantees judge by the courts (or when the maximum period of 180 days has been exhausted), the investigation judge will become the judge of the guarantees of the specific case; In other words, the jurisdiction of the guarantee judge, once the complaint or claim has been received, the matter will be referred to the competent judge for the investigation and trial of the matter.

Already ADI 6,305 (2020d) [27], prosecuted on $01 / 20 / 2020$, whose subject is similar to those that appear in the other Addis, was distributed to Minister Luiz Fux, for prevention, and was conclusive for the Vice Presidency on the same date, by virtue of article 13, paragraph VIII, and article 14 of the Internal Regulations of the STF.

Upon examining the request, Minister Luiz Fux granted the precautionary request filed by the author entity monocratically, determining

1. The revocation of the monocratic decision contained in Ads 6.298, 6.299, 6.300 and the suspension sine die of effectiveness, until the Plenary can rule on question:

- Of the implementation of the guarantee judge and his advisers (articles 3bis, 3ter, 3quater, 3quinquies, 3sexies, 3 septies of the Code of Criminal Procedure).

- On the modification of the judge who heard evidence declared inadmissible (art. 157 of the Criminal Procedure Law).

In addition, precautionary measure

2. Was granted to suspend, sine die, the effectiveness, ad referendum of the Plenary.

- Of the modification of the filing procedure of the police investigation (art. 28, caput, of the Criminal Procedure Code).

- Of the liberalization of the prison for not holding the custody hearing within 24 hours (Article 310, §4, of the Criminal Procedure Code).

In which despite proposing, at the beginning of the decision, that "it is not for the Supreme Court to make an eminently political judgment of what is good or bad, convenient or inconvenient, appropriate or inappropriate" highlighting, among others, Levinson's doctrine (2016) $[29,30]$, the points on which the reasons for decision have been organized, on the contrary, demonstrate precisely something that reflects, in truth, purely consequentialist activism. 
In summary, three points, in the Minister's opinion, have drawn attention to the highlighted conclusions.

The first of them consisted in the affirmation that the fact that the questioned law has been approved by the National Congress and sanctioned by the President of the Republic does not function as an apt argument to minimize the legitimacy of the Judicial Power for the exercise of control of constitutionality. The very debate on the concept and, above all, the limits of the legitimacy of the Constitutional Courts allow conclusions close to discretion.

As a second point, it was identified that, despite the fact that the Constitution and jurisprudence authorize "the adoption of interpretation and decision techniques that function, in practice, as increases to the content of the legislation that is the object of control", referred to as "techniques are proper of the examination of the merit of the application and can only be used in specific cases, such as to enable a systemic reading of the legal norms, to remedy ambiguities that may exist in the legal text, to fill the content of open clauses or, even, to calibrate practical difficulties related to the application of the declaration of unconstitutionality "(2020) [19].

The third point refers to the fact that the decision that will be issued in the framework of the direct action of unconstitutionality, specifically in the examination of the precautionary application, has a "reduced scope, under pain of damaging the deliberation that will be carried out later by the Plenary of the court." It should be noted that the "safeguard of the reversibility of the precautionary measure" and the "prestige of the deliberation on the merits of the plenary session" have been used as arguments to reconsider the previous decision of the Minister President, Minister Dias Toffoli.

Regarding the prestige of the deliberation of merit to be carried out by the Plenary, in the examination made in said decision on the institution of the judge of guarantees and related norms (Articles $3 \mathrm{~A}$ to $3^{\mathrm{o}}-\mathrm{F}$ of the Code of Criminal Procedure), the merit of ADI 6,305 (2020d) [27], for example, at the time of the examination of a possible formal unconstitutionality due to a defect of initiative, at which time an express comparison was made on the difference between criminal procedure rules, which would not involve any irregularity, of those related to judicial organization, kind of rules in which we would be faced with possible formal unconstitutionalities [31].

Possible doubts about whether the discussion regarding the classification of the norms subject to constitutionality control in norms of judicial organization or criminal procedure implies (or not) the discussion of the merit of the claim and, consequently, the role of the Plenary is reserved, are discarded when, throughout the decision itself, the speaker Minister cites as a previous example of his work in which it is the judgment, carried out by the Plenary, of the merit of ADI n. 4,414 (2013) [32] at which point the examination of the classification of norms in procedure or judicial organization has been cited, with good reason.

It can be verified that, at this point, the scope of the decision, unlike the starting points, that is, the interpretative rules established by the rapporteur Minister, was broad, which caused damage, at least potential, reduced, to harm the deliberation to be carried out later by the Plenary of the Court (2020) [19]. Regarding the joint examination of the formal unconstitutionality and the real life data, the Minister Rapporteur expressly stressed that "In any case, these real life data are essential for the analysis of the formal unconstitutionality of the attacked devices, in the insofar as they lead to an inescapable conclusion: the institution of the judge of guarantees materially alters the division and organization of judicial services to such a level that it demands a complete reorganization of the country's criminal justice (2020) [19].

With regard to the elements relating to material unconstitutionality, the rapporteur Minister, once again going beyond the strict limits of the decision that he himself imposed at the beginning of the decision, highlighted as premises two groups of arguments, consisting of the absence of:

- Budget allocation.

- Previous impact studies for the application of the measure and the impact of the measure on the efficiency of the Brazilian mechanisms to fight crime.

Another point of the monocratic decision issued in ADI n. 6.305 (2020d) [27] that draws attention refers to the use, at that procedural moment, of the Cherry-picking mechanism [33], to rule out the "success" of the institute of the judge of guarantees in another country without due care to justify the reasons why the comparison would really fit the paradigm.

In this sense, the use of examples of what is happening in Germany, Italy and Portugal would require caution. Not only Cherry-picking, but also the very concept of legal transplants and the corresponding criteria provided by Deo Campos D, et al. [34] refer to the substance of the discussion on ADI 6.305 itself ${ }^{6}$. In addition to these aspects, the possible increase in

6 On the subject, the following passage from the analyzed decision confirms the affirmative, but let's see: "In the case on screen, the comparative analysis of the guarantee judge demands the observance of other issues, such as (i) the capacity that The Brazilian judicial system has for the reception of the "Judge of Guarantees" (eg the procedural contingent, as well as the human and financial resources available); (ii) the proximity and / or 
the time of the process and the incentives for impunity, based on the works of Gilberto José S, et al. [35,36], also refer to the merit of the question raised under the aegis of constitutional jurisdiction.

After analyzing the precedents of the Federal Supreme Court, regarding the examination of criminal law and criminal procedure, pronounced between the years 2018 and 2020, the central question of the present study is examined, which is: to what extent would it be It is possible to divide the concept of purely consequentialist activism into degrees according to the legal nature of the decision issued in the sphere of the Supreme Federal Court, more specifically, regarding the (non) provisional nature of the decision.

\section{The Measurement, based on Degrees, of the (In) Existence of the Purely Consequentialist Legal Activism in Monocratic Decisions issued in the Sphere of the Supreme Federal Court}

Professor Gilmar Ferreira Mendes drew attention to the action $^{7}$ of the Federal Supreme Court by issuing monochromatic decisions of a liminal nature when in the exercise of constitutional jurisdiction, proposing

- Not to grant monochrome decisions.

- Having conditions for postponement, if the matter of the Constitutional Court would have been taken immediately to the Plenary.

From this weighting arose, together with the reading of the concept developed by Georges A, et al. [1], the academic interest in deepening the subject and in the possibility of measuring, from degrees, gives (in) existence of purely consequentialist legal activism in monochrome decisions issued in the sphere of the Supreme Federal Court.

In other words, to establish whether, and to what extent, it would be possible to divide the concept of purely consequentialist activism into degrees according to the legal nature of the decision issued in the sphere of the Supreme Court, more specifically as regards (not) provisional character of the decision.

institutional link between the prosecution and prosecution bodies in the countries in question; (iii) the regulations on the powers of the guarantee judge in the countries compared. In truth, it is also essential to precisely analyze the comparative experiences that have been unsuccessful, in which the institution has been implemented, but has not obtained the expected results and and/or was subsequently deleted "(STF, ADI 6,305 MC / DF Dje 02/03/2020).

7 Said demonstration took place during an online class given on 09.04.2020, in the discipline of the Doctorate "Contemporary Challenges of the Constitutional Order".
It is observed, from Georges A, et al. [1], that the concept of normative consequence is neutral and can generate both positive and negative decisions.

The analysis of the Supreme Court precedents has shown, in the previous topic that we are dealing with decisions or sentences characterized by purely consequentialist judicial activism of all the outstanding precedents, the monocratic decision issued in ADI 6,305 (2020d) [27] has attracted the most attention, either due to procedural episodes, or due to the conclusions present there and, mainly, the breach of the established parameters in the act itself that allows the precautionary examination of questions relating to the judge of guarantees.

It is not the objective of this study to make value judgments about the benefits and harms of purely consequential activist decisions or sentences. The central objective, I repeat, is whether, and to what extent, it would be possible to divide the concept of purely consequentialist activism into degrees according to the legal nature of the decision rendered in the sphere of the Supreme Court, more specifically as regards ( no) provisional nature of the decision.

On all the precedents analyzed in the previous topic, consisting of ADI n. 5526/ DF (2018a) [15], in Criminal Action n. 937 (2020d) [27] and in Criminal Investigation n. 4.435 / DF (2019a) [17] it is possible to verify that they are purely consequentialist activist jurisdictional provisions of the first degree, that is, that they refer to collegiate resolutions issued by the Federal Supreme Court, respecting the

- $\quad$ Principle of collegiality.

- The limit possible interpretative regarding the merits of the claim.

Already the Suspension of Judicial Order n. 1178 / PR (2018c) [18] and the Precautionary Measure in ADI n. 6.298 (2020a) [19], in that although they can also be classified as purely consequential activist decisions, they should be considered, contrary to the first group, as belonging to the second degree by virtue of:

- The non-observance of the existing limit when examining precautionary measures.

- Therefore of the principle of collegiality.

Given this classification, it is possible to infer that purely consequential activist decisions could be dictated within the system proposed by Professor Gilmar Ferreira Mendes, that is, if they are not granted monocratically as a rule, or, in the event that the necessary conditions for This means that the provisional judicial resolution is carried out immediately to the Plenary for the deliberation of the Constitutional Court. 


\section{Conclusion}

The present study, based on the analysis of legal Consequentialism and the concept of purely consequentialist judicial activism brought by Georges A, et al. [1], has tried to analyze whether, within this concept, it would be possible to divide it into degrees based on the legal nature of the decision issued, more specifically with regard to the (non) provisional nature of the decision and its effects on the constitutional jurisdictional provision.

For this, a retrospective study of the so-called analysis of consequences in law was carried out in the first topic, the objective of which was to establish the parameters for the study of said theory, either at the international or national level. Two theoretical milestones were used at this point: Lionel Adolphus H, et al. [5] and Ronald D, et al. [3,4]. As regards the first, it has been seen that, while easy cases would give clear answers to the interpreter, difficult cases, characterized precisely by the absence of such answers, have allowed the interpreter to resolve the case based on discretion.

Regarding the second theoretical framework, it has been seen that, by associating Law and integrity, even if the interpreter is faced with what said author calls a hard case; he will not be able to appeal to pure and simple discretion. On the contrary, difficult cases must be resolved by investigating, by the judge, the rights of each of the parties in the case that is being processed. That is, even if the specific case does not allow a clear answer, even in that hypothesis, the judge, departing from discretion, must resolve the problem on the basis of principled arguments.

Arguments of principle refer to the standards that justify a political decision, showing that it respects or protects the rights of an individual or group. The verification of Law as integrity for Ronald D, et al. [4], therefore, is not more than guaranteeing predictability in decisions, but also confers legitimacy to the judicial decision by maintaining the chain of meanings determined by previous decisions, that is, there is the prioritization of community principles.

Then, in this chapter, from what should be understood by consequentialism and its relationship with moral philosophy Tim M, et al. [8]; CHISTOPOULOS [9], with the classical utilitarian tradition Julia D, et al. [7]; John Stuart M, et al. [10], their differences with respect to utilitarianism, their relationship with pragmatism in a broad sense Richard $\mathrm{R}$, et al. [11]; William J, et al. [12] and the legal Richard P, et al. 13], having highlighted the legal concept Bryan AG, et al. [14], it was seen that, for Neil M, et al. [2], the scope of the arguments of consequence and the possible risks of its use by judges, in particular those exercising constitutional jurisdiction.
In this sense, in addition to extracting the rule to be adopted to measure the existence of the phenomenon in Brazil (consequentialist judicial activism), that is, the use of some single and final criterion that could serve as a "rule to calculate the cost - cost-benefit of the consequences derived from the decision taken Georges A, et al. [1], it was possible to highlight the specific questions that had to be answered throughout the jurisprudential analysis. From this construction, it was possible to preliminarily conclude that, in the analyzed precedents, the action of the Federal Supreme Court occurred within the perspective of consequentialist judicial activism, having been used at various times as a rhetorical subterfuge to substitute the current law for the subjectivity or, occurring, for several times, reference to the so-called "unique rules" and there is no correlation between the theoretical outputs chosen with empirical data that could serve as superfluous to the debated consequences.

The examination of the consequences pursued in the activity of the judge, as well as the examination of the efficient legal argumentation (and possible risks) allowed us to extract the concept of purely consequentialist judicial activism so that, then, the jurisprudential analysis of said institute would be possible within the framework of the Supreme Federal Court. Next, in the second topic, precedents judged by the Federal Supreme Court, in criminal matters, between 2018 and 2020 , were analyzed so that it was possible to determine if said courts serve as an example of purely consequential activist positions, reaching the conclusion affirmative for that questioning.

In this sense, the following precedents tried at the Federal Supreme Court were analyzed:

- $\quad$ Adin n. 5526 / DF (2018a) [15].

- Criminal Action n. 937 (2018b) [16].

- Criminal Investigation n. 4,435 / DF (2019a) [17].

- Suspension of Liminar n. 1178 / PR (2018c) [18].

- Precautionary measure in ADI n. 6,298 (2020a) [19].

In the third topic, from the theoretical bases of legal Consequentialism, purely consequentialist activism and the possible correlations of being made with the precedents chosen for study, it was possible to respond to the research problem that was proposed at the beginning, which is: in What measure would it be possible to divide the concept of purely consequentialist activism into degrees according to the legal nature of the decision issued in the sphere of the Supreme Federal Court, more specifically, regarding the (non) provisional nature of the decision.

In this sense, based on the comparison between the modality of sentence issued in the jurisprudence of the Supreme Federal Court selected, in which it was possible to see that both the Plenary and the Ministers, monocratically, 
made decisions of an efficient nature, characterizing examples of activism purely consequentialist, it was possible to divide the concept of purely consequentialist activism into degrees according to the legal nature of the decision rendered in the sphere of the Supreme Federal Court of all the outstanding precedents, the monocratic decision issued in ADI 6,305 (2020d) [27] has attracted the most attention, either due to procedural episodes, or due to the conclusions present there and, mainly, the breach of the established parameters in the act itself that allows the precautionary examination of questions relating to the judge of guarantees.

On all the precedents analyzed in the previous topic, consisting of Adin n. 5.526/DF (2018a) [15], in Criminal Action n. 937 (2018b) [16] and in Criminal Investigation n. 4.435/DF (2019a) [17] it is possible to verify that they are purely consequentialist activist jurisdictional provisions of the first degree, that is, that they refer to collegiate resolutions issued by the Federal Supreme Court, respecting the:

- Principle of collegiality.

- The limit possible interpretative regarding the merits of the claim.

Already the Suspension of Judicial Order n. 1178 / PR (2018c) [18] and the Precautionary Measure in ADI n. 6.298 (2020a) [19], in which although they can also be classified as purely consequential activist decisions, they should be considered, contrary to the first group, as belonging to the second degree by virtue of

- The non-observance of the existing limit in the examination of measures. Precautionary and, consequently.

- Of the principle of collegiality.

Given this classification, it is possible to infer that purely consequential activist decisions could be dictated within the system proposed by Minister Gilmar Ferreira Mendes, that is, if they are not granted monocratically as a rule, or, in the event that the conditions for their implementation are met. Approval either the provisional jurisdictional procedure immediately taken to the Plenary for the deliberation of the Constitutional Court having been ignored, therefore, art. 20, of the Law of Introduction to Brazilian Law -LINDB, therefore, abstract legal values were applied without considering the practical consequences of the decision.

That is, it was classified as purely consequentialist activism of the first degree, on the one hand, the sentences dictated by the Plenary of the Brazilian Constitutional Court more specifically and, on the other, those of the second degree, characterized by monocratic decisions dictated within the scope of the STF of an efficient scientific nature, something that should be avoided in order to guarantee, the Brazilian constitutional jurisdiction, the due legal security in the handling of constitutional questions.

\section{References}

1. Georges A (2019) Legal consequentialism: the place of consequence analysis in law and the dangers of consequentialist judicial activism. Review of the Courts 1009: 1-9.

2. Neil M (2005) Rethoric and the rule of law: a theory of legal reasoning. Oxford: Oxford University Press.

3. Ronald D (1978) Taking rights seriously. Massachusetts: Harvard University Press.

4. Ronald D (1986) Law's Empire. Cambridge: Harvard University Press.

5. Lionel Adolphus H (2009) The concept of law. Trans. Antônio de Oliveira Sette-Câmara. São Paulo: WMF Martins Fontes.

6. Nicola A (1998) Dictionary of Philosophy. São Paulo: Martins Fontes.

7. Julia D (2012) Consequentialism. London: Routledge.

8. Tim M (2001) The Demands of Consequentialism. Oxford: Oxford University Press.

9. Chistopoulos (2014) Brazil Georges Campos. Control of constitutionality of budget norms: The use of consequentialist arguments in Supreme Court decisions. Thesis (Doctorate in Law) University of São Paulo, Brazil.

10. John Stuart M (2007) Utilitarianism. Trans. Rita de Cassia G. Neiva. São Paulo: Escala.

11. Richard R (2008) What is the truth for? Trans. Antonio Carlos Olivieri. São Paulo: UNESP Publisher.

12. William J (2006) Pragmatism. Trans. Jorge Caetano da Silva. São Paulo: Martin Claret.

13. Richard P (2003) Law, Pragmatism and Democracy. Cambridge/London: Harvard University Press.

14. Bryan AG (2005) Black's Law Dictionary. $9^{\text {th }}$ (Edn.), St. Paul: Thomson Reuters.

15. (2018a) Federal Court of Justice. Full Court. Direct unconstitutionality action no. 5.526/DF. Brazil.

16. (2018b) Federal Court of Justice. Full Court. Criminal Action No. 937. Brazil.

17. (2019a) Federal Court of Justice. Full Court. Criminal Investigation no. 4.435/DF. 
18. (2018c) Federal Court of Justice. Monocratic decision. Suspension of Injunction no. 1178/PR. Brazil.

19. (2020a) Federal Court of Justice. Full Court. Direct unconstitutionality action no. 6,298. Brazil.

20. (1988) Presidency of the Republic. Civil House. Deputy Chief of Legal Affairs. Brazil.

21. Andyara Klopstock S (2012) Parliamentary immunities in Brazilian constitutional law. University of São Paulo, Brazil.

22. (1965) Law no. 4,737. Criminal Code. Brasília, DF, 1965.

23. (1941) Decree-Law No. 3689 of 1941. Code of Criminal Procedure. Brasília, DF, Brazil.

24. (2020b) Federal Court of Justice. Full Court. Direct unconstitutionality action no. 6,299. Brazil.

25. (2019b) Law no. 13,964 of 2019. Improves criminal law and criminal procedure. DF, Brazil.

26. (2020c) Federal Court of Justice. Full Court. Direct unconstitutionality action no. 6,300. MC on ADI 6,300. Brazil.

27. (2020d) Federal Court of Justice. Full Court. Direct unconstitutionality action no. 6,305. MC on ADI 6,305. Brazil.

28. (1990) Law no. 8038 of 1990. Establishes procedural norms for the processes that it specifies, before the Superior Court of Justice and the Federal Supreme Court. Brazil.

29. Daryl L (2020) Rights Essentialism and Remedial Equilibration. Columbia Law Review 99(4): 857-940.

30. Daryl L (2016) Foreword: Looking for Power in Public Law. Harvard Law Review 130(1): 131-143.

31. José Frederico M (1960) Judicial Organization and Process. Journal of Civil Procedural Law, São Paulo, Brazil 1.

32. (2013) Federal Court of Justice. Full Court. Direct unconstitutionality action no 4.414 . Brazil.

33. Andrew F (2011) Beyond Cherry-Picking: Selection Criteria for the Use of Foreign Law in Domestic Constitutional Jurisprudence. Suffolk University Law Review 44: 873-889.

34. Deo Campos D (2018) Legal Transplants: history, theory and criticism in Comparative Law. Journal of the Faculty of Law at UFRGS. Porto Alegre 39: 76-96.

35. Gilberto José S, Francisco Assis SP (2001) Crime Economy: theoretical elements and empirical evidence. Economic Analysis Magazine, Faculty of Economic Sciences, UFRGS, and Porto Alegre 19(36): 195-217.

36. (2013) OAK, Cristiano. Tax Decision Theory. São Paulo: Saraiva, Brazil. 